\title{
Comment
}

\section{Institutions and economic history: a critique of professor McCloskey}

\author{
A VNER GREIF \\ Stanford University, Department of Economics, Stanford, California and CIFAR, Toronto, Ontario, Canada \\ (avner@stanford.edu)
}

JOEL MOKYR

Northwestern University, Department of Economics, Evanston, Illinois

\begin{abstract}
Professor McCloskey makes many telling and insightful points in her survey and criticism of what she terms the new institutional economics; yet there are a number of shortcomings to her paper. One is that she has bundled together a variety of quite disparate approaches to the role institutions play, and refers to them as 'neo-institutionalist'. We unbundle these different strands, and show that an undifferentiated critique is unwarranted. A second argument made by her is that an institutional approach cannot explain either the Industrial Revolution or what she calls 'the Great Enrichment'. We show that this conclusion is unwarranted and results from an overly narrow definition of institutions.
\end{abstract}

There is something almost ironic in reading an essay in which McCloskey (2015) tries to demolish the idea that institutions played an important role in modern economic history; after all, if the field of economic history is itself to have institutions, she might qualify as one. Always larger than life, her eloquent and erudite work and conversation over a long career have been invariably influential, respected, and provocative, her criticism insightful and informed. Her taking-on of an entire literature in economics in this essay is a good example of her courage and panache. In her skepticism of the importance of institutions in economic history she is not alone, and joined for instance by Clark (2007) with whom she otherwise disagrees on most other issues (McCloskey, 2010, Chapters 30-32).

In her critique, she attacks a body of literature which she terms at times 'Samuelsonian' or 'Northian' or 'neo-institutionalist' but these terms seem all synonymous and interchangeable. To us, the lumping together of quite different bodies work as the ones by North, Acemoglu, Greif, and the World Bank, in a rather cartoonist depiction of a complex body of work, and summarized by 'add institutions and stir' seems to obfuscate matters more than it clarifies.

*Email: j-mokyr@northwestern.edu 
Although all of the work on institutions mentioned above - and many others beside - seem to agree that 'institutions' matter, they often mean quite different things by the concept. What they share - as surely does Professor McCloskey - is a sense of dissatisfaction with the economics of the 1960s and 1970s, with its emphasis on individual rationality and the lack of attention to any kind of heterogeneity, interaction with others, belonging to a collective identity, or a set of shared beliefs. Since the seminal work of Douglass North, many scholars have turned to these issues and tried to make progress in a variety of ways, some of which may turn out to be more fruitful than others. Tarring them all with the same brush as suffering from static assumptions and having little historical power does not much advance our understanding; accusing them of ignoring a wide literature that might be relevant somehow without specifying how, precisely, they should deploy the 'exact and gigantic literature about ideas, rhetoric, ideology, ceremonies, metaphors, stories, and the like' (p. 27) seems to advance us by very little.

The accusation that institutional economics is but a mindless extension of neoclassical economics ('Max U' in McCloskey's terms) seems unhelpful. If we are to make any progress on the issues that she wants us to advance on such as 'human meaning' and 'ethical persuasion' (p. 40), it would be useful to know how and why people believe what they believe and how they change their minds. This, indeed, is what a lot of recent cutting-edge economic research is about (for a survey, see Alesina and Giulano, 2014).

A perusal of the institutional literature as applied to economic history and the distribution of wealth and prosperity in the world today yields a number of strands that resemble one another much less than Professor McCloskey's lumping of them would suggest. The idea of institutions-as-rules, originally proposed by North $(1981,1990)$, was soon realized to be limited in scope. Yet, it was rhetorically powerful. It demonstrated the benefit of incorporating institutional features in neo-classical economics, even without violating the rationality and self-interest assumptions central to it. North thereby induced a seminal departure from the long tradition in the economic field of considering markets as somehow detached from the influence of political or social factors.

The analytical framework that North (1990) originally advanced held that economic institutions are rules originating through interactions among utility maximizing political agents. Although the institutions-as-rules framework is parsimonious and ignores important institutional features, as North explicitly noted (e.g., North, 2005), it was applied widely and effectively. It was particularly useful in the 'institutions as power' school of New Institutional Economics (NIE) of which Acemoglu and Robinson $(2006,2012)$ are the bestknown spokesmen. Here the emphasis is first and foremost on distribution and the deployment of political power in determining economic outcomes. Issues such as 'the commitment problem' and 'constraints on the executive', first put forward in North and Weingast's (1989) classic and influential paper on the 
topic and heavily used in empirical work on institutions, come to the fore here. This approach, too, has little in common with Professor McCloskey's depiction of the neo-institutional school - indeed, the two concepts are never mentioned in her essay despite their centrality in this literature, and she never refers to the North-Weingast paper.

McCloskey (2015) carefully delineates her view regarding the limitations of the institutions-as-rules approach. In particular, she emphasizes that rules do not constrain behavior ('rules are, well, rules', p. 2) and that institutionalized behavior is often followed without enforcement by that state. Institutionalized behavior, she notes, reflects the morally appropriate and socially accepted. While North focuses on institutionalized rules that people are forced to follow, Professor McCloskey focuses on the motives that make people follow a rule of behavior through their beliefs and norms, which are in her view the linchpin of institutions. In a sense, North sees the polity as the source of institutions while Professor McCloskey argues that beliefs and preferences - most of us would call it 'culture' - as the root factor that makes institutions work. Economists have recently gotten interested in culture, as they have reached the same conclusion as Professor McCloskey: we cannot understand institutions without culture (Bisin and Verdier, 2011; Fernández, 2011; Greif, 1994). We're not all Max U's anymore.

Her criticism is especially otiose, however, because the literature has long recognized that rules are, well, rules and that motivation is the linchpin of institutions. One work that expresses this view is Greif (2006). He noted that rules 'are nothing more than instructions that can be ignored. If prescriptive rules of behavior are to have an impact, individuals must be motivated to follow them... By 'motivation' I mean here incentives broadly defined to include expectations, beliefs, and internalized norms' (p. 7). Furthermore, 'taking the reasons that people follow rules as exogenous to the analysis, as North's institutions-as-rules approach does, is clearly useful for various purposes, but it is limiting to consider motivation as exogenous' (p. 39). In short, 'motivation $\ldots$ is the linchpin of institutions, as it mediates between the environment and behavior' (p. 45).

The associated research agenda (often referred to as institutions-as-equilibria) also recognizes that institutions are 'negotiated' in the terminology advocated by Professor McCloskey. Institutions are considered an equilibrium outcome in the interactions among individuals (for a recent discussion, see Greif and Kingston, 2011). An institution as a system of rules, beliefs, expectations, and norms perpetuates only if it elicits behavior that is consistent with the rules, that reaffirms the associated beliefs and expectations, and that replicates its underpinning norms. Institutions influence agents' behavior and their behavior, in turn, shapes these institutions. We still have much to learn about institutions from this perspective but the challenge is not about what should be done, as Professor McCloskey asserts, but about how to do so. 
That said, McCloskey's essay raises an important question: Can institutions explain the rise of modern economic growth and the factor of 100 (or 2030) by which she reckons economic welfare and incomes have increased in the past two centuries? Good institutions explain better-functioning markets, better allocations (see her figure on p. 12), a better provision of public goods, and the repair of market failures. Higher trust in the enforcement of contracts and the security of property rights will encourage trade and the operation of financial and labor markets that require an expectation that one's partners will not behave opportunistically. That may well have happened, she feels, but it does not have enough explanatory power or 'oomph' in McCloskey's immortal term. More is needed. Institutions cannot explain the modern world.

Much of this critique seems apposite. To be sure, big differences between the economic performances of nations can at times be explained by political and institutional differences. The 'natural experiments' of societies that started out with similar cultures and histories and were arbitrarily split into different institutional regimes (Korea and Germany come to mind) with spectacularly different outcomes, have been the most powerful rhetorical tool that those advocating institutions have come up with. Acemoglu and Robinson start off with two cities on different sides of the US-Mexican border. Others might point to the gap in economic performance in the past decades between countries with palpably weak institutions such as Ukraine and others such as Poland and Estonia with better ones.

But what may be a powerful tool in cross-section differences in the wealth of nations may not work in long time series: Can institutions explain the rise of the modern economies after 1750? Can they explain the telegraph, internal combustion engines, the Haber-Bosch process, and anesthesia? Some scholars, including North himself, have tried that argument, pointing for example to intellectual property rights as a source of innovation, or the rise of the modern nation state and the nationalism it spawned as a source of economic advancement (Greenfeld, 1992). Institutions might have spurred innovations. But here McCloskey's skepticism is well placed, and requires a serious response.

To make any progress, it makes sense to divide the matter up into the original discoveries and inventions that actually pushed the envelope outward and created a new cutting edge of technology, and the diffusion of the new ideas and their adoption by other economies that were perhaps not the technological leaders but in a strong position to imitate the leadership fairly soon. Professor McCloskey focuses on British innovations in the Industrial Revolution and searches in vain for the institutions that might explain that. 'Institutions, such as corporate law, changed after the ethical change' (p. 22) that brought about the Industrial Revolution.

Ethics may have changed but the lack of changes in various rules during the English Industrial Revolution is no evidence that institutions did not change. Formal rules, after all, are not quite the same as 'institutions' implying that 
a stability of the former does not imply lack of change in the latter. The same politically proclaimed rules can be a component of distinct institutions depending on the associated expectation, beliefs, and norms. Understanding institutions and their impact requires going deeper than considering their observable components, namely, rules. Corporate law, in the case of England, may have remained the same, but corporations - as an institution on the ground - might have changed. In fact, the evidence reveals that some innovation-facilitating institutional changes took place in England around the time of the Industrial Revolution. In other words, Professor McCloskey relies on the definition of institutions she rejects in evaluating the role of institutions in the Industrial Revolution.

Consider, for example, the English patent system regarding which there were no meaningful statutory changes between the Statue of Monopoly of 1624 and an act passed in 1852. The patent records, nevertheless, reveal important institutional changes. In the early years of the patent system, the Crown extensively used it to extract rent and exercise patronage. The resentment to the monopolies generated in this way was so intense that the Long Parliament, in the context of the Civil War, closed the Patent Office. Although the Crown reopened the office after the Restoration in 1660, it responded to the antimonopoly cultural resentment. After the restoration, the Crown no longer relied on monopolies issued by the patent office to generate rent (MacLeod, 1988: 20-22).

The poor relief system was another social institution that drastically changed during that period although its transformation was not always reflected in its formal rules. Poor relief was important in the first transition to the modern economy because it fostered social order in a period of radical structural transformation. England's transition to a modern economy involved at times introducing labor-saving technologies and in many cases devalued existing skills and human capital. Although welfare enhancing in the long run, this transition caused considerable pain in the short run because job losses were unavoidable. Yet, it was not checked by collective violence by those who lost their source of livelihood despite the scarcity of alternative employment. 'Labor saving innovations entailed negative pecuniary externalities. Those whose labor is no longer needed and their livelihood thus threatened might respond violently, and their expected response undermines the incentive to innovate' (Greif and Iyigun, 2013, p. 534).

The English poor relief system was not originally created to facilitate innovations, as Slack (1999) has demonstrated. In the 16th century, civic humanism and political centralism were important interests shaping policy toward the poor. By the mid-17th century, these 'absolutist' initiatives appeared 'bankrupt intellectually because they were bankrupt financially' (ibid.: 74). By the late 18th century, however, contemporaries recognize the role of poor relief in fostering disruptive and labor-saving innovations. One prominent observer, Sir F.M. Eden, noted in his 1797 book on poverty that 'machines or contrivances calculated to 
lessen labour ... throw many industrious individuals out of work; and thus create distresses that are sometimes exceedingly calamitous. Still, however, as the only point of view, in which a nation can regard such schemes of a reform, is to consider how far they actually do or do not promote the general wealth, by raising the largest quantity of provisions, or materials for manufacture, at the least cost, their inconvenience to individuals will be soften and mitigated, indeed, as far as it is practical' by helping the poor (1797, vol. 1, p. xiv).

Over time, the English poor relief system became more comprehensive, more predictable, and better financed than ever before and relative to other states (Solar, 1995). From the late 17th to the late 18th century, poor relief expenditure in England rose from less than 1\% of GDP to about 2\% and poor relief expenditure per capita in England was seven times higher than in France (ibid.: 7). The amount may seem modest compared to relief provided by the modern welfare state, but it was significant relative to the income of those it was designed to assist. Around 1685, poor relief in England amounted to $31 \%$ of the income of the lower $25 \%$ of wage earners and by 1803 it increased to $32 \%$ of the lower $30 \%$ wage earners. ${ }^{1}$

The role of poor relief in maintaining social order is evident from examining the recipients of poor relief. Originally, the system was designed and mainly applied to provide for those who were unable to provide for themselves. Among them were the elderly, the insane, the disabled, the homeless (known as 'vagabonds and vagrants' at the time), and households headed by women. Following the Industrial Revolution, however, there was a remarked shift toward providing temporary, or occasional, poor relief. The occasionally poor were individuals who found themselves in temporary need for help because of unemployment, sickness, or high cost of food. Notably, the transition was particularly pronounced in the newly industrialized areas in the North and West (King, 2000, chapter 7). Systematic data is available for the first time in 1803 and then for 1813,1814 , and 1815 and reveal that between $40 \%$ and $45 \%$ of the recipients were only occasionally supported. ${ }^{2}$

The Acts of Parliament that governed the poor relief system do not reveal this new idea regarding this role of the poor relief. The Old Poor Law of 1601 was in force until 1834, although it was occasionally modified by Parliament such as Gilbert's Act of 1782 and the establishment of the Speenhamland System in 1795. While the overall framework of the Poor Law may seem immutable, it changed quite a bit underneath the surface. Similar to the case of the English patent system, focusing on the formal rules is insufficient to understand the institution.

1 Data limitation prevents from symmetrically calculating the share of poor relief to income in both periods. The calculations are based on the following sources. GDP: Broadberry et al (2011). Income: Milanovic, Lindert and Williamson (2011). Poor relief: Eden (1797, vol. 1, p. 230; for 1685) and Abstract of the Answers 1803-4, p. 714.

2 Marshall (1835: 34); Abstract of the Answers 1803-4, p. 715. 
But what is clear is that the local authorities who administered the law came to understand the needs to maintain social order and to support those victimized by technological progress. Without those evolving beliefs, the Industrial Revolution might have run into serious resistance and possibly might have been derailed by a massive popular uprising.

Institutions that increased the value of an innovation, such as a patent system, and maintain social order in periods of transition, such as poor relief, may not have been sufficient to foster innovations. Other institutions that lead to conservatism or technological inertia may counter their impact. Institutions that increased the material benefit from inventing cannot explain innovations per se more than the existence of a police force can explain low criminal activity. Patents and the Poor Law were supporting institutions, but what needs to be explained is where technological creativity came from in the first place, and what institutions made it grow so remarkably in the 18th century.

In fact, during the Great Enrichment, another institution seems to have been important in motivating inventions. As Professor McCloskey well knows, a substantial amount of the new technology of the British Industrial Revolution and the applied science and mathematics that formed its epistemic base - such as it was - came from the European Continent. The institutions that supported a transnational community of scholars, philosophers, and experimentalists in the centuries before the Industrial Revolution provide part of the answer to McCloskey's query (Mokyr, 2016). On the eve of the Industrial Revolution, Western Europe had developed a set of institutions that supported, encouraged, and incentivized the kind of research that eventually allowed Europeans to harness electricity, produce cheap steel, and deploy chemical fertilizers.

So here is Professor McCloskey's fundamental misconception: she argues that institutions pertained to matters such as law and order, property rights, good governance, and the efficient provision of public goods, and reckons that they are, even taken together, incapable of explaining the 'Great Enrichment'. It is innovation that did the job, she argues. No contest, but we submit that innovation, too, needed institutional support. The dismissal of the importance of Intellectual Property Rights (IPR's) and the patent system by her (the Poor Law does not come up in her account) will not quite do.

The age preceding the Industrial Revolution was characterized by a wellorganized intellectual community that more and more rewarded and encouraged thinking outside the box and proposing new ways to harness natural laws and regularities 'for the relief of Man's estate' as Francis Bacon, its intellectual founding parent, famously put it. This community falls squarely inside any definition of institutions, and in terms of its impact on subsequent economic development it was clearly at least as important as any nation state, with or without constraints on the executive. Before we dismiss the role of institutions in the emergence of modern economies, we should take account of this one, which thus far has not figured prominently in the institutional literature. 
Contemporaries saw the institution as one, and explicitly compared it to the nation state. They called it the Respublica Litteraria, and thought of themselves as 'citizens' (Fumaroli, 2015; Grafton, 2009). In 1751, Voltaire (ever Francocentric) wrote in his Age of Louis XIV that 'During the Age of Louis XIV, a Republic of Letters was established, almost unnoticed, despite the wars and despite the difference in religions ... all the sciences and arts received mutual assistance this way ... True scholars in each field drew closer the bonds of this great society of minds, spread everywhere and everywhere independent ... this institution is still with us, and is one of the great consolations for the evils that ambition and politics have spread through the earth' (Voltaire [1753] 1785, Vol. 21, p. 287). These 'citizens' saw each other as fellow members, and while they naturally disagreed with one another, they shared many preconceptions and beliefs. Among those that were critical to subsequent economic development were the belief that all new knowledge was to be distributed and shared, and that if it was found by others to be persuasive and valuable, that the first proponent would receive 'credit' and that the enhanced reputation would be associated with potential enhanced standing and prestige among her or his peers. The most celebrated citizen of the Republic of Letters, Isaac Newton, was rewarded with a plumb patronage job and a royal-style burial site at Westminster Abbey in 1727. Being an innovator was appreciated.

How critical was the Republic of Letters in bringing about economic modernity and the Great Enrichment? Some of its most distinguished citizens, such as Descartes, Spinoza, Leibniz, and Newton, are among the giants whose contribution to modern thinking is still fundamental to the intellectual history of the West. But did they contribute to economic growth? The case is not obvious and Professor McCloskey has elsewhere (McCloskey, 2010, Chapter 38) taken a strong position against a big role of scientific knowledge in economic development at least before the 20th century. To see why this position is mistaken, it is important to look at the contribution of others, perhaps slightly less prominent citizens. Some of the great insights of the Industrial Revolution demanded a scientific mind, if not necessarily a full scientific understanding of the issues at hand. 'Fortune favors the prepared mind' said Pasteur, and many of the great advances of the Industrial Revolution or the era that followed were made by men who had been in touch with natural philosophers, mathematicians, chemists, and other trained and learned people, absorbed their culture and exposed to their rigor and precision.

The networking between the great engineers and entrepreneurs of the era and those on the cutting edge of science in Edinburgh, Birmingham, London, and Paris at the time has been too well documented to need elaboration here (Jacob, 2014; Mokyr, 2009). Many of the great scientists of the age, such as René Reaumur, Nicolas Leblanc, and Claude Berthollet in France, Joseph Priestley and Humphry Davy in Britain, Carl Linnaeus in Sweden, Benjamin Franklin in the American colonies, Alessandro Volta and Lazzaro Spallanzani in Italy pursued 
agendas informed and motivated by pragmatic considerations of production in agriculture and manufacturing: science and technology aided and abetted one another. These were all citizens of the Republic of Letters, sharing its culture and its norms. Many of the more difficult challlenges, such as the harnessing of electricity and the manufacturing of cheap steel, defied them for generations, but they never stopped trying.

The technological advances of the Industrial Revolution made the world richer because entrepreneurs and states adopted them far from the places where they were first invented. British jennies and steam engines were adopted in Saxony, Alsace, Switzerland, and Flanders within decades of their first operation in the Midlands. Railways, gas lighting, and the use of steam-powered pumps were adopted by firms all over Europe and North America, as the technology of the Industrial Revolution spread in concentric circles in the north Atlantic region. But for this to happen, institutions had to guarantee that those who made profits could keep them, that workers would get paid as promised, and that coal would arrive on time to fuel the new locomotives so that passengers would arrive at their destinations on schedule. For this to happen, actors also had to know with high certainty that those they contracted with would meet their commitments, and that predatory agents - government or private - would not expropriate the surplus. There was, in other words, a strong complementarity between institutions and technological innovation. To say that Europe was propelled only by technology or only by better institutions would be like arguing that a bicycle was ridden only by the front or the back wheel. Both had to be in place (Mokyr, 2006).

Professor McCloskey's own formulation here is helpful: she argues that institutions (N) alone could not have brought about growth (G); it needed also ideas (D). But much of her thinking seems to suggest that she accuses the 'neoinstitutionalists' of arguing either that $G=f(N)$ or at least that $G=f(N+D)$, which makes the two substitutes: if you cut $\mathbf{N}$ but increase $\mathrm{D}$, you could get the same result. We would argue that the world was closer to a formula such as $\mathrm{G}=\min (\mathrm{N}, \mathrm{D})$, that is, they were strong complements, or at least that the world was $G=f\left(N^{a} D^{b}\right)$ which is a relation half-way between perfect substitutes and perfect complements. The great fortune of 18th-century Europe was that Enlightenment thinking advanced on both fronts, and that it was sufficiently influential to be implemented in most Western countries by 1815 or so, to lead to a Great Enrichment. Other parts of the world, which did not adopt institutional change, discovered that just adopting the technology without the accompanying institutional reforms would lead to serious imbalances and instability that would turn out hard to fix. Just ask Mikhail Gorbachov. Or Hassan Rouhani.

A second layer of criticism by Professor McCloskey consists of the argument that Britain underwent no serious institutional changes between 1700 and 1850: 'what actually changed in the eighteenth century in Britain was $\mathbf{D}$ (ideas), not $\mathbf{N}$ 
(institutions)' (p. 24), and that a time traveler would not find the institutions of 1830 very different from those of 1630 (p. 22). Since on the surface $\mathbf{N}$ did not change much, and the rest of the economy did, it follows that institutions did not matter much according to Professor McCloskey.

As we have already seen, institutions may have changed more in the period leading up to the Industrial Revolution than Professor McCloskey allows for. The logic does not follow, however, even aside from the history. Institutions may still have been a necessary condition to accommodate the innovations that followed; had Britain in 1630 had the institutions, say of the Ottoman Empire or Ming China, the work of Newcomen, Desaguliers, or Smeaton might have been received very differently, to say nothing of Harrison, Priestley, or Jenner. That said, the premise seems to be based on a rather extreme interpretation of British history, in which neither the Civil War, the Restoration, nor the Glorious Revolution mattered one whiff. Professor McCloskey knows British history too well to argue this seriously (McCloskey, 2016). One may differ from the NorthRobinson-Pincus interpretation that sees 1688 and the ensuing imposition of Dutch institutions on England and find breakpoints either before in the Civil War era or a later point of Whig rule. But all historians, excepting perhaps the eccentric J.C.D. Clark, agree that in 1830 it was a very different place.

One way or another, British institutions were changing, as people's ideas about what was good government and how a good and moral society was supposed to work changed, as they read their Locke and their Toland. To be sure, Britain was a conservative society in which political and social institutions changed gradually and which eschewed Bastille-storming or Winter Palace conquests. But the slow and deliberate pace at which Britain gradually dismantled its ancien régime in the late 18th and early 19th century should fool no one.

One of the more remarkable phenomena of the later period was the decline of corruption (Mokyr, 2009: 424-26). Far from being thoroughly corrupt throughout the period as Professor McCloskey asserts, British institutions remarkably cleared themselves from the blatant rent-seeking that characterized the age of Walpole. As Harling (1996) has shown in a remarkable book that should be mandatory reading to anyone doubting the rate of institutional change in Industrial Revolution Britain, politicians like Burke, Pitt the younger, and Shelburne basically eliminated the vast bulk of political patronage from the scene. The ruling class had become, in Linda Colley's term, a service elite, who brought to government a new approach that consisted of professionalism, hard work, and uncompromising private virtue which proved remarkably effective (Colley, 1992: 192). By 1830, Wellington said that as prime minister he commanded virtually no patronage (Rubinstein, 1983: 57). There remained a few bad apples, but the post-1830 Whig reforms effectively disposed of most of those as well. By the mid-1830s, the cost of all unreformed sinecures was estimated at under $£ 17,000$, down from $£ 2,00,000$ two decades earlier (Harling, 1995: 136). 
Despite the arguments to the contrary by Acemoglu and Robinson, political institutions and raw power were not all there was to the role of institutions in the Great Enrichment. A substantial part of the conversation in the new institutional economics - not acknowledged by Professor McCloskey - concerns the strange and slightly oxymoronic concept of 'social capital'. Here too, we take exception to the statement that institutions were irrelevant and changed but little in an otherwise rapidly changing world. As Clark (2000) has shown in another book that should be on the reading list of all institution-deniers, 18th-century Britons did not bowl alone.

The late 17th century had witnessed the expansion of the coffee- and chocolate-houses, in which members of a new commercial and intellectual urban elite congregated (Cowan, 2005). The 'associational society' described in details by Clark (2000), while not entirely new in the 18th century, expanded enormously after 1750. It was felt, especially in the closing decades of the century, that the state was failing to create order and stability in an increasingly volatile society and that citizens had to create their own public goods through collective action (Clark, 2000: 94-96; see also Sunderland, 2007; 50-84).

Some segment of this social capital had a direct effect on the growth and dissemination of useful knowledge through various scientific societies, of which the Lunar Society of Birmingham is the most famous. Most others had social and cultural functions. Social networks of this kind were essential if markets were to exist and contracts to be honored. They reflected and reinforced the underlying culture of respectable and 'polite' conduct, precisely the kind of values that Professor McCloskey has emphasized in her magisterial trilogy on bourgeois values. British Masonic lodges and friendly societies provided mutual insurance and widows' pensions, but they also cemented commercial regulations and allowed investors to invest in projects they knew little about but whose entrepreneurs they knew personally and therefore felt they could trust. To illustrate the importance of trust, Pearson and Richardson (2001) have argued that the entrepreneur in the Industrial Revolution was heavily diversified. Rather than a sharply focused single-minded owner-manager who spent his entire life on the one business he built, the typical entrepreneur of the age of the Industrial Revolution diversified into non-core ventures. Cotton masters and other textile producers in Manchester, Leeds, and Liverpool could be found as directors of insurance companies, canal and turnpike companies, gas companies, telegraph lines, banks, and other sectors. This channel is one of the many through which social capital enriched industrializing societies.

This account of the Industrial Revolution is perfectly consonant with the neo-institutionalist view of the world. It explains how and why the capital that embodied the new techniques accumulated rapidly, how would-be entrepreneurs were induced to take risks and work their heads off in the hope of success. We should never forget that the people who introduce new technology in the production sphere do this in a certain institutional environment that affects the 
way the new products or method will be made and marketed, how it will be financed, marketed, and the expert workers recruited. New technology emerges in an economy in which one expects things to work, others to keep their word and show up on time. That, too, belongs to the category of institutions. On this last point, we hope, Professor McCloskey will agree with us.

\section{References}

Abstract of the Answers and Returns Made Pursuant to an Act, Passed in the 43d Year of His Majesty King George III. 1803-04 Intituled, 'An Act for Procuring Returns Relative to the Expense and Maintenance of the Poor in England', Ordered by the House of Commons, Miscellaneous Papers, Sess, Vol. XIII. London.

Acemoglu, D. and J. Robinson (2006), 'De Facto Political Power and Institutional Persistence', American Economic Review, 96(2): 325-330.

Acemoglu, D. and J. Robinson (2012), Why Nations Fail: The Origins of Power, Prosperity, and Poverty, New York: Crown.

Alesina, A. and P. Giuliano (2014), 'Culture and Institutions'. Unpublished ms.

Bisin, A. and T. Verdier (2011), 'The Economics of Cultural Transmission and Socialization', in J. Benhabib, A. Bisin and M. O. Jackson (eds.), Handbook of Social Economics, vol. 1A, the Netherlands: North-Holland, pp. 339-416.

Broadberry, S., B. Campbell, A. Klein, M. Overton and B. v. Leeuwen (2011), 'British Economic Growth, 1270-1870: An Output-based Approach', London: London School of Economics (LSE).

Clark, G. (2007), A Farewell to Alms, Princeton: Princeton University Press.

Clark, P. (2000), British Clubs and Societies, 1580-1800: The Origins of an Associational World, Oxford: Clarendon Press.

Colley, L. (1992), Britons: Forging the Nation, 1707-1837, New Haven, CT: Yale University Press.

Cowan, B. (2005), The Social Life of Coffee: The Emergence of the British Coffeehouse, New Haven, CT and London: Yale University Press.

Eden, F. M., Sir, (1797), The State of the Poor; Or, An History of the Labouring Classes in England, from the Conquest to the Present Period, vols. I-III. London: J. Davis.

Fernández, R. (2011), 'Does Culture Matter?', in J. Benhabib, M. O. Jackson and A. Bisin (eds.), Handbook of Social Economics, vol. 1A, the Netherlands: North-Holland, pp. 481-510.

Fumaroli, M. (2015), La République des Lettres, Paris: Gallimard.

Grafton, A. (2009), 'A Sketch Map of a Lost Continent: the Republic of Letters', The Republic of Letters: A Journal for the Study of Knowledge, Politics, and the Arts, 1(1) :1-18. Repr. In Worlds made by Words: Scholarship and Community in the Modern West, Cambridge, MA: Harvard University Press, pp. 9-34.

Greenfeld, L. (1992), Nationalism: Five Roads to Modernity, Cambridge, MA: Harvard University Press.

Greif, A. (1994), 'Cultural Beliefs and the Organization of Society: A Historical and Theoretical Reflection on Collectivist and Individualist Societies', Journal of Political Economy, 102(5): 912-950.

Greif, A. (2006), Institutions and the Path to the Modern Economy: Lessons from Medieval Trade, Cambridge: Cambridge University Press. 
Greif, A. and M. Iyigun (2013), 'Social Organizations, Violence, and Modern Growth', American Economic Review, 103(3): 534-38.

Greif, A. and C. Kingston (2011), 'Institutions: Rules or Equilibria?', in G. Caballero and N. Schofield (eds.), Political Economy of Institutions, Democracy and Voting, Spinger, Berlin: Springer-Verlag Berlin Heidelberg, pp. 13-44.

Harling, P. (1996), The Waning of 'Old Corruption': The Politics of Economical Reform in Britain, 1779-1846, Oxford: Clarendon Press.

Jacob, M. C. (2014), The First Knowledge Economy, Cambridge: Cambridge University Press.

King, S. (2000), Poverty and Welfare in England 1700-1850, Manchester: Manchester University Press.

MacLeod, C. (1988), Inventing the Industrial Revolution: The English Patent System, 16601880. Cambridge: Cambridge University Press.

McCloskey, D. (2010), Bourgeois Dignity: Why Economics Can't Explain the Modern World, Chicago: University of Chicago Press.

McCloskey, D. (2015), 'Max U vs. Humanomics: A Critique of Neo-Institutionalism', Journal of Institutional Economics, published online. DOI: 10.1017/S1744137415000053.

McCloskey, D. (2016), The Treasured Bourgeoisie: How Markets and Improvement Became Virtuous, 1600-1848, and Then Suspect, Chicago: University of Chicago Press, forthcoming.

Milanovic, B., P. H. Lindert and J. G. Williamson (2011), 'Preindustrial Inequality', Economic Journal, 21: 255-272.

Mokyr, J. (2006), 'The Great Synergy: The European Enlightenment as a Factor in Modern Economic Growth', in W. Dolfsma and L. Soete (eds.), Understanding the Dynamics of a Knowledge Economy, Cheltenham: Edward Elgar, pp. 7-41.

Mokyr, J. (2009), The Enlightened Economy, New York and London: Yale University Press.

Mokyr, J. (2016), A Culture of Growth: Origins of the Modern Economy, Princeton: Princeton University Press, forthcoming.

North, D. C. (1981), Structure and Change in Economic History, New York: W. W. Norton.

North, D. C. (1990), Institutions, Institutional change, and Economic Performance, Cambridge: Cambridge University Press.

North, D. C. (2005), Understanding the Process of Economic Change, Princeton: Princeton University Press.

North, D. C. and B. R. Weingast (1989), 'Constitutions and Commitment: Evolution of Institutions Governing Public Choice in Seventeenth Century England', Journal of Economic History, 49(4): 803-832.

Pearson, R. and D. Richardson (2001), 'Business Networking in the Industrial Revolution', Economic History Review, 54(4): 657-679.

Rubinstein, W. D. (1983), 'The End of “Old Corruption” in Britain 1780-1860', Past and Present, 101, 55-86.

Slack, P. (1999), From Reformation to Improvement: Public Welfare in Early Modern England, Oxford: Oxford University Press.

Solar, P. M. (1995), Poor Relief and English Economic Development before the Industrial Revolution, The Economic History Review, New Series, 48(1): 1-22.

Sunderland, D. (2007), Social Capital, Trust and the Industrial Revolution, 17801880, London and New York: Routledge.

Voltaire [1753] (1785), Siècle de Louis XIV, Oeuvres Complètes de Voltaire, vol. 21. Basel: Jean Jacques Tourneisen. 